\title{
SOIL EROSION ASSESMENT IN SOUTHERN EVIA ISLAND USING USLE AND GIS
}

\begin{abstract}
Bathrellos. G.D. ${ }^{1}$, Skilodimou H.D. ${ }^{1}$, and Chousianitis K.G. ${ }^{2}$
${ }^{1}$ Department of Geography \& Climatology, Faculty of Geology \& Geoenvironment, National \& Kapodistrian University of Athens, University Campus, Zografou, 15784 Athens, Greece, gbathellos@geol.uoa.gr

${ }^{2}$ Department of Geography \& Climatology, Faculty of Geology \& Geoenvironment, National \& Kapodistrian University of Athens, University Campus, Zografou, 15784 Athens, Greece, hskilodimou@geol.uoa.gr

${ }^{2}$ Space Applications Research Unit in Geosciences, Department of Geophysics - Geothermics, Faculty of Geology and Geoenvironment, National and Kapodistrian University of Athens, 15784 Zografou, Athens -

Greece,chousia@geol.uoa.gr.
\end{abstract}

\begin{abstract}
In the present study the evaluation of soil erosion in Southern Evia Island was carried out. Data related with precipitation, morphology, land cover and lithology were collected. A spatial database was created and the further processing of the collected data was prepared using GIS. The Universal Soil Loss Equation (USLE) was used to predict the spatial distribution of the average annual rate of erosion. Five major factors were used to calculate the soil loss. These are rainfall erositivity $(R)$, soil erodibility $(K)$, slope length and steepness $(L S)$, cropping management $(C)$ and conservation supporting practice $(P)$. Each factor is the numerical estimate of a specific condition that affects the severity of soil erosion. The obtained soil loss values were used to create the erosion risk map. The applied methodology provides a cost effected and rapid estimation of areas that are vulnerable to soil erosion and need immediate attention from soil conservation point of view. Moreover these results can be used to assist land use planning.
\end{abstract}

Key words: Soil erosion risk, USLE, Southern Evia Island, GIS

\section{Introduction}

Soil erosion is one form of soil degradation and is a naturally occurring process on all land, whose agents are water and wind. Soil erosion may be a slow process that continues relatively unnoticed, or it may occur at an alarming rate causing serious soil loss. Soil loss and its associated impacts are important and widespread environmental problems today, which have far-reaching economic, political, social and environmental implications due to both on-site and off-site damages (Thampapillai and Anderson, 1994). The main on-site impact is the reduction of soil quality which caused by the loss of the nutrient-rich upper layers of the soil and the reduced water-holding capacity of many eroded soils. In addition, the soil that is detached by accelerated water or wind erosion may be transported at considerable distances. This gives rise to the off-site problems. Water erosion's main offsite effect is the movement of sediment and agricultural pollutants into watercourses. This can lead to the disruption of the ecosystems of lakes, and contamination of drinking water. Another major offsite impact results from the agricultural chemicals that often move with eroded sediment (Dregne, 2002; Descroix and Mathys, 2003). 


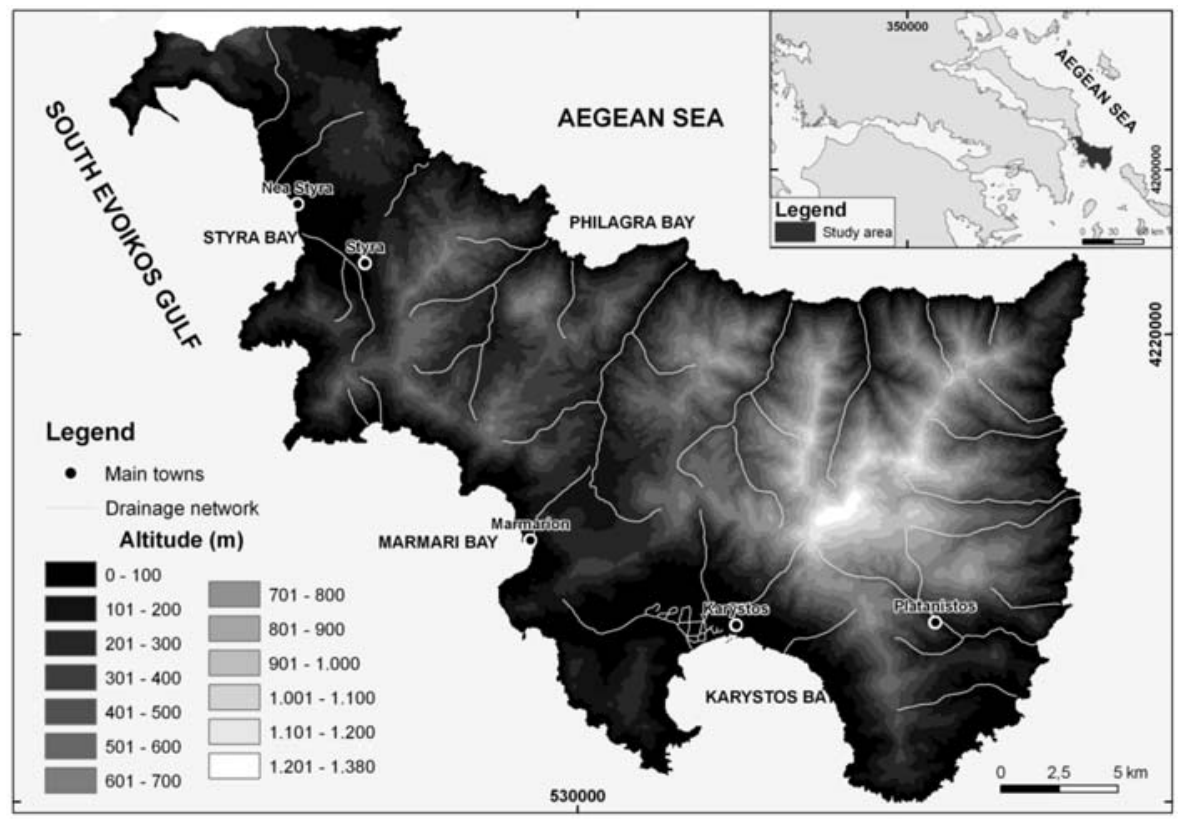

Fig. 1: The digital elevation model (DEM) of the study area superimposed by drainage network and main towns. The inset at upper right shows the location of the study area within the Greek territory.

The object of this study is to determine the areas most threatened by soil erosion by implementing the widely applied Universal Soil Loss Equation (USLE) of Wischmeier and Smith (1978) in Geographical Information System (GIS). GIS permits effective and accurate application of the USLE model in grid environment, which would allow us to analyse soil erosion in great detail. Precipitation, morphology, lithology and land cover spatial databases were constructed in the analysis and maps relevant to soil erosion were created using the GIS capabilities. The case study of the present paper is Southern Evia Island, Central Greece, which covers an area of about $602 \mathrm{~km}^{2}$ with altitudes varying between 0 and $1380 \mathrm{~m}$ (Fig.1).

\section{Methods}

\subsection{USLE equation}

The Universal Loss Equation (USLE) is an equation that predicts the amount of soil lost per acre per year due to soil erosion The USLE equation has been developed by Wischmeier and Smith (1978). This equation was the first empirical erosion equation that was not tied to a specific region, thus the title "Universal" Soil Loss Equation, and has been used in more than 100 countries. Five major factors are used to calculate the soil loss for a given site. Each factor is the numerical estimate of a specific condition that affects the severity of soil erosion at a particular location. The values reflected by these factors can vary considerably due to varying weather conditions. Therefore, the values obtained from the USLE more accurately represent long-term averages and the soil erosion is estimated as follows:

$$
\mathrm{A}=\mathrm{R} \times \mathrm{K} \times \mathrm{LS} \times \mathrm{C} \times \mathrm{P}
$$


Where $\mathrm{A}$ is the average annual soil loss rate ( $\mathrm{t}$ ha- 1 year-1), $\mathrm{R}$ is the rainfall erosivity factor $(\mathrm{MJ} \mathrm{mm}$ ha- $1 \mathrm{~h}-1$ year-1), $\mathrm{K}$ is the soil erodibility factor ( $\mathrm{t}$ ha $\mathrm{h}$ ha- $1 \mathrm{MJ}-1 \mathrm{~mm}-1$ ), $\mathrm{LS}$ is the topographic factor (unitless), $\mathrm{C}$ is the cropping management factor (unitless) and $\mathrm{P}$ is the erosion control practice factor (unitless). The units of average annual soil loss rate (A) are carried by the $\mathrm{R}$ and $\mathrm{K}$ factors. These two factors represent the cause and effect of soil erosion. The $\mathrm{R}$ factor represents the erosive power of rainfall on the soil regardless of what type of soil it is, while the $\mathrm{K}$ factor represents the extent that the specific soil type resists erosive forces. The remaining USLE factors (LS, C and P) may be thought of as adjustment factors. In the present study the soil loss in Southern Evia Island was estimated on a 20x20 m cell basis resolution by overlaying the five digital parameter layers (R, $\mathrm{K}, \mathrm{LS}, \mathrm{C}$ and $\mathrm{P}$ ) in raster format after some modifications in the calculation of the $\mathrm{K}$ factor.

\subsection{Development of model database for USLE}

To apply the USLE, a spatial database including precipitation, morphology, land cover and lithology was constructed using ArcGIS software (ESRI, 2005). The factors for the USLE equation were calculated and extracted from the spatial databases. Individual GIS files were built for each factor in the USLE and combined by cell-grid procedures in GIS to predict soil loss in the spatial domain. The dataset that was available consisted of the following:

- A Digital Elevation Model (DEM), which is a representation in raster format of the surface of the study area. The Digital Elevation Model was created at $20 \mathrm{~m}$ resolution by digitizing the contours of "Karistos" and "Platanistos" topographic map-sheets on a scale of 1:50.000, published by the Hellenic Military Geographical Service.

- The IGME "Karistos-Platanistos" (1991) and "Rafina” (1977) geological maps scanned from the corresponding paper map-sheets.

- The land cover in vector format (polygon layer) from CORINE database on a scale of 1:100.000.

- Meteorological tabular data (temperature and rainfall) from Karistos, Marathonas and Rafina meteorological stations of the Hellenic National Meteorological Service.

The R, K, LS and C factors which are required in calculating soil erosion from USLE were extracted from the spatial database. In the following sections we describe these factors respectively.

\section{RAINFALL EROSIVITY FACTOR}

The R-factor represents the erosivity of the climate at a particular location and evaluates the erosive potential of the rainfall. It is the average yearly sum of the products of the kinetic energy of each storm with the maximum 30 minute rainfall intensity of the storm. The energy of a given storm depends upon all the intensities at which the rain occurred and the amount of precipitation that is associated with each particular intensity value. However, in this application the lack of a dense meteorological network in the broader study area made us use the linear equation of Van der Knijff et al. (2000) which calculates the R-factor as a function of the mean annual rainfall (mm):

$$
\mathrm{R}=\mathrm{a} * \mathrm{Pj}
$$

where $\mathrm{Pj}$ is the mean annual rainfall $(\mathrm{mm})$ and the coefficient $\alpha=1.3$. Monthly meteorological tabular rainfall data of 11-14 years was used to calculate the R-factor for the weather stations Karystos, Marathonas and Rafina, whose mean annual rainfall calculated to be $700.4 \mathrm{~mm}, 397.0 \mathrm{~mm}$ and $357.6 \mathrm{~mm}$ respectively. Finally, the Inverse distance weighting (IDW) interpolation method was applied to produce the spatial layer of the R-factor. 


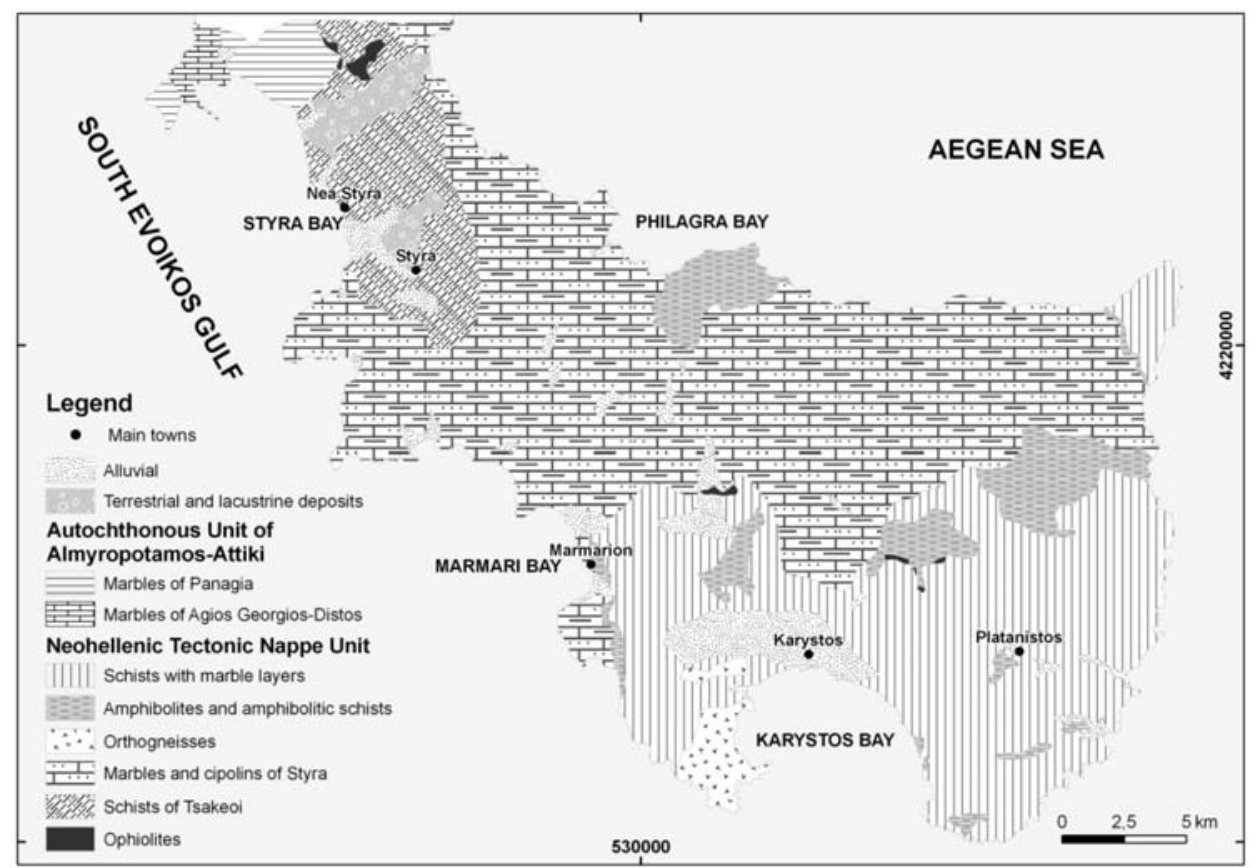

Fig. 2: Simplified geological map of Southern Evia Island (based on the Geological Maps of IGME 1:50.000, Karistos-Platanistos and Rafina sheets).

\section{SOIL ERODIBILITY FACTOR}

The K-factor is an empirical measure of soil erodibility and is a function of intrinsic soil properties. Erodibility varies with soil texture, aggregate stability, infiltration capacity and organic and chemical content (Karydas et al., 2009). This factor is influenced by the detachability of the soil, by the infiltration and runoff and the transportability of the sediment eroded from the soil. The main soil properties affecting the K-factor are soil texture, including the amount of fine sand in addition to the usual sand, silt and clay percentages used to describe soil texture, organic matter, soil structure and the permeability (Wischmeier et al. 1971; Mitchell and Bubenzer 1980; Dabral et al. 2001). Foster et al. (1991) proposed the following equation for the calculation of the K-factor:

$$
\mathrm{K}=2.8 \cdot 10-7 \mathrm{M} 1.14(12-\mathrm{a})+4.3 \cdot 10-3(\mathrm{~b}-2)+3.3(\mathrm{c}-3)
$$

Where $\mathrm{M}$ is the particle size parameter (\% silt $+\%$ very fine sand) $\mathrm{x}(100-\%$ clay), a is the organic matter content $(\%), \mathrm{b}$ is the soil structure code (very fine granular $=1$, fine granular $=2$, coarse granular $=3$, lattice or massive $=4$ ) and $\mathrm{c}$ is the soil permeability class (fast $=1$, fast to moderately fast $=2$, moderately fast $=3$, moderately fast to slow $=4$, slow $=5$, very slow $=6$ ). These values are applied for soil erodibility factor when a soil map is available.

However, in this work the K-factor was calculated from the geological maps, due to unavailability of precise and reliable soil datasets for the study area. The geological formations were derived from the geological map sheets of Karistos-Platanistos (IGME, 1991) and Rafina (IGME, 1977). Formations from the Autochthonous unit of Almyropotamos-Attiki and the Neohellenic tectonic nappe unit participate in the geological structure of the study area. More specifically, the geological for- 
Table 1. Classification of the geological formations and estimated soil erodibility factor values.

\begin{tabular}{|l|c|}
\hline Lithology & K Factor \\
\hline Marbles & 0,0005 \\
\hline Marbles and cipolins with schists intercalations & 0,001 \\
\hline Ophiolites & 0,007 \\
\hline Orthogneisses & 0,0003 \\
\hline Schists & 0,009 \\
\hline Schists with marble layers & 0,006 \\
\hline Alluvial and near shore deposits & 0,02 \\
\hline Terrestrial and lacustrine deposits & 0,02 \\
\hline
\end{tabular}

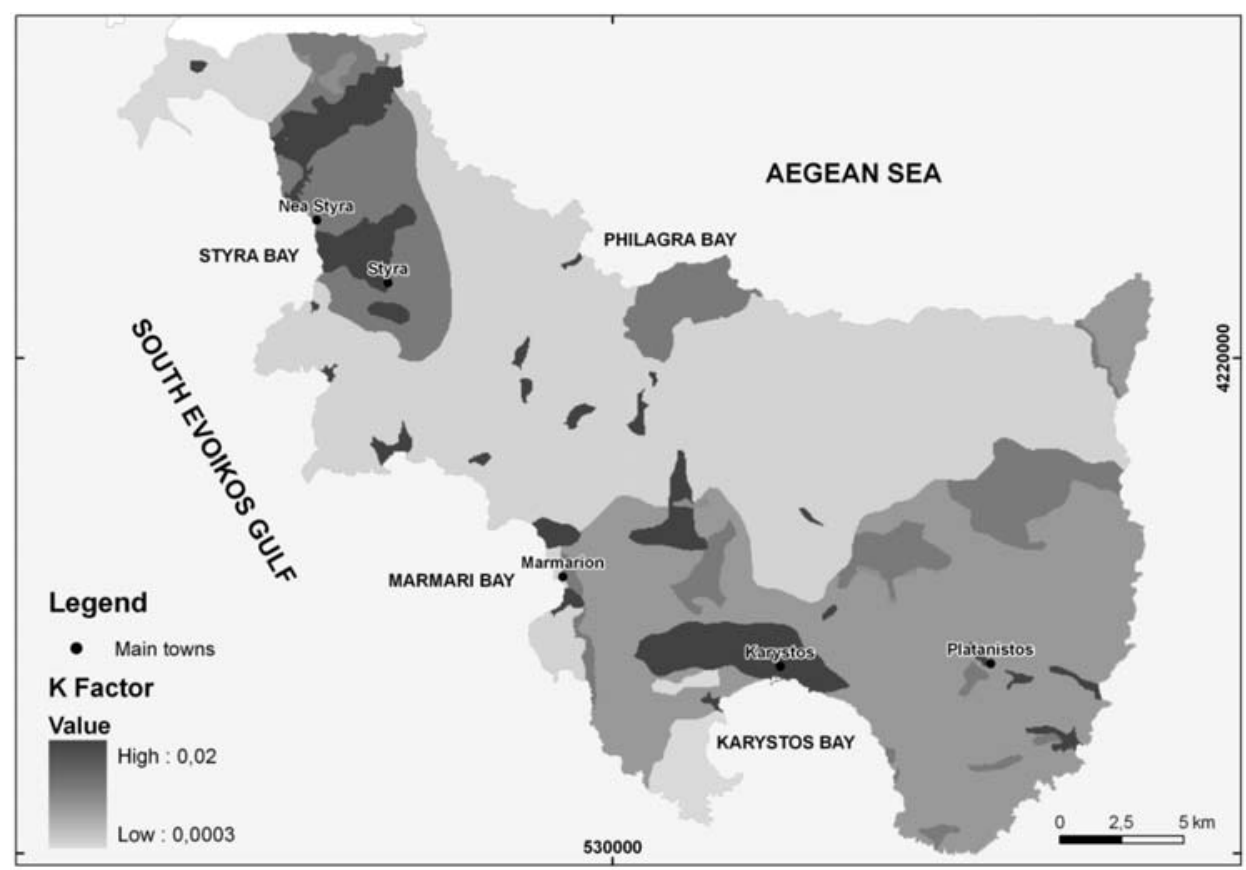

Fig. 3: Spatial distribution map of the soil erodibility factor in the study area.

mations that were identified are alluvial, terrestrial and lacustrine deposits, marbles of Panagia and Agios Georgios-Distos (Autochthonous unit of Almyropotamos-Attiki), schists with marble layers, amphibolites and amphibolitic schists, orthogneisses, marbles and cipolins of Styra, schists of Tsakeoi and ophiolites (Neohellenic tectonic nappe unit). The simplified geological map of the study area are shown in Fig.2.

The formations were classified according to parent material and depending on their sensitivity to erosion, their infiltration capacity, their aggregate stability and their organic and chemical content. Val- 


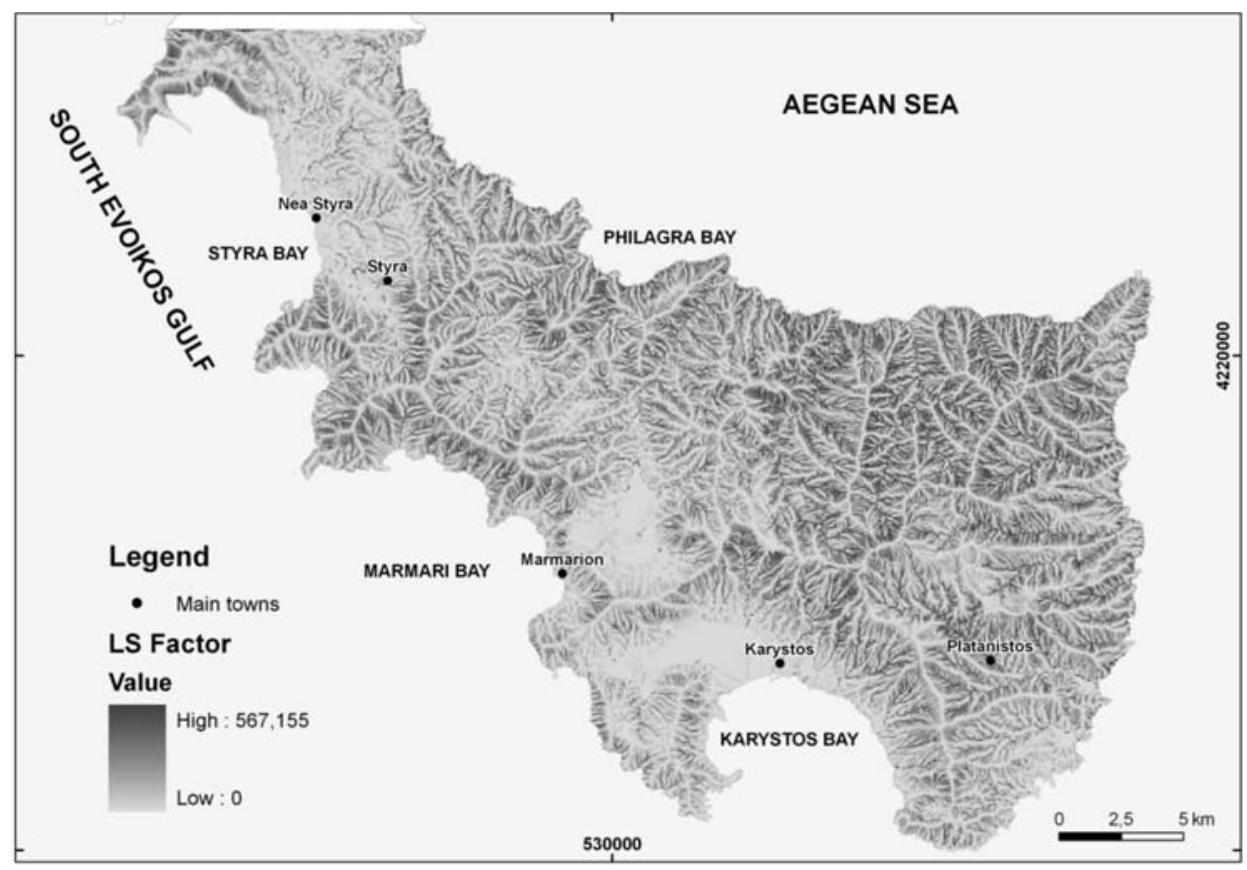

Fig. 4: Spatial distribution map of the topographic factor in the study area.

ues of K-factor were assigned in every formation, computed for every grid cell and producing the $\mathrm{K}$-factor map. Soil erodibility factor was found to be in the range between $0.0003-0.02$ (Table 1). The spatial distribution of the K- factor is presented in Fig. 3.

\section{TOPOGRAPHIC FACTOR}

This factor can be divided into L and S factors that respectively account for slope length and slope steepness and jointly they refer to the topographic (or relief) influence on erosion intensity. Naturally, the steeper the slope of a field, the greater the amount of soil loss from erosion (Desmet \& Govers 1996). Soil erosion also increases as the slope length, which is defined as the distance from the origin of overland flow to the point where deposition begins to occur, increases due to the greater accumulation of runoff. The topographic factor can be determined by multiplying the L and S factors. The technique for estimating the LS-factor was proposed by Moore and Burch (1986 a and b) using equations such as

$$
\mathrm{LS}=(\text { Flow Accumulation } \mathrm{x} \text { Cell Size/22.13) } 0.4 \mathrm{x}[\sin (\text { Slope } \mathrm{x} \text { 0.01745/0.0896) }] 1.3
$$

In this study, both the flow accumulation and the slope steepness were estimated from the Digital Elevation Model (resolution $20 \mathrm{~m}$ ) of the study area, after the required processing. Finally, the LSfactor was found to be in the range of 0.1 to 567.155 and its spatial distribution is shown in Fig. 4 .

\section{CROPPING MANAGEMENT FACTOR}

The $\mathrm{C}$ factor reflects the effect of cropping and management practices on the soil erosion rate and it is mainly related to the vegetation's cover percentage. Undisturbed forests and dense grass provide the best soil protection and are about equal in their effectiveness. Forage crops are next in ef- 
Table 2. Cropping management factor for different land cover classes.

\begin{tabular}{|l|c|}
\hline Land cover. & C Factor \\
\hline Non-irrigated arable land & 0,250 \\
\hline Permanently irrigated land & 0,300 \\
\hline Vineyards & 0,350 \\
\hline Olive groves & 0,400 \\
\hline Pastures & 0,010 \\
\hline Complex cultivation patterns & 0,170 \\
\hline Land principally occupied by agriculture, with significant areas of natural vegetation & 0,200 \\
\hline Broad-leaved forest & 0,001 \\
\hline Coniferous forest & 0,001 \\
\hline Mixed forest & 0,001 \\
\hline Natural grassland & 0,010 \\
\hline Sclerophylous vegetation & 0,009 \\
\hline Transitional woodland-shrub & 0,009 \\
\hline Bare rock & 0,450 \\
\hline Sparselly vegetated areas & 0,350 \\
\hline Burned areas & 0,550 \\
\hline
\end{tabular}

fectiveness, because of their relatively dense cover. Small grains, such as wheat, provide intermediate cover and offer considerable obstruction to surface wash. Row crops, such as corn, offer relatively little living cover during the early growth stages and thereby leave the soil susceptible to erosion, unless residues from previous crops cover the soil surface (Brady and Weil 1999). In the present study, the $\mathrm{C}$-factor values were derived from the CORINE land cover database on a scale of 1:100.000. The study area was classified into 17 land cover classes (Table 2). For each land cover class a corresponding $\mathrm{C}$-factor value was given by utilising the values given in the literature (Wischmeier and Smith 1978, Cebecauer et al. 2000), adjusted for the present study area. Urbanized areas were excluded from the evaluation, while attention was given at the areas that were affected by the wildfires of 2007 and 2009. The largest value was assigned at these areas, which were determined by photo-interpretation using MODIS Terra satellite images of the study area. Finally, the map and the distribution of land cover C-factor values are shown in Fig. 5.

\section{EROSION CONTROL PRACTICE FACTOR}

P-factor reflects the effects of practices such as construction of terraces or contour strips that will reduce the amount and rate of the water runoff and thus reduce the amount of erosion. Wischmeier and Smith (1978) defined the P-factor as the ratio of soil loss with a specific support practice to the corresponding soil loss with up and down cultivation. The lower the P-value, the more effective the conservation practice is considered to be at reducing soil erosion. However, in the present study, the P value 1.0 was assigned, because on a scale of 1:50.000 it was not possible to obtain data regarding support practices.

\section{Results}

\section{SOIL EROSION POTENTIAL}




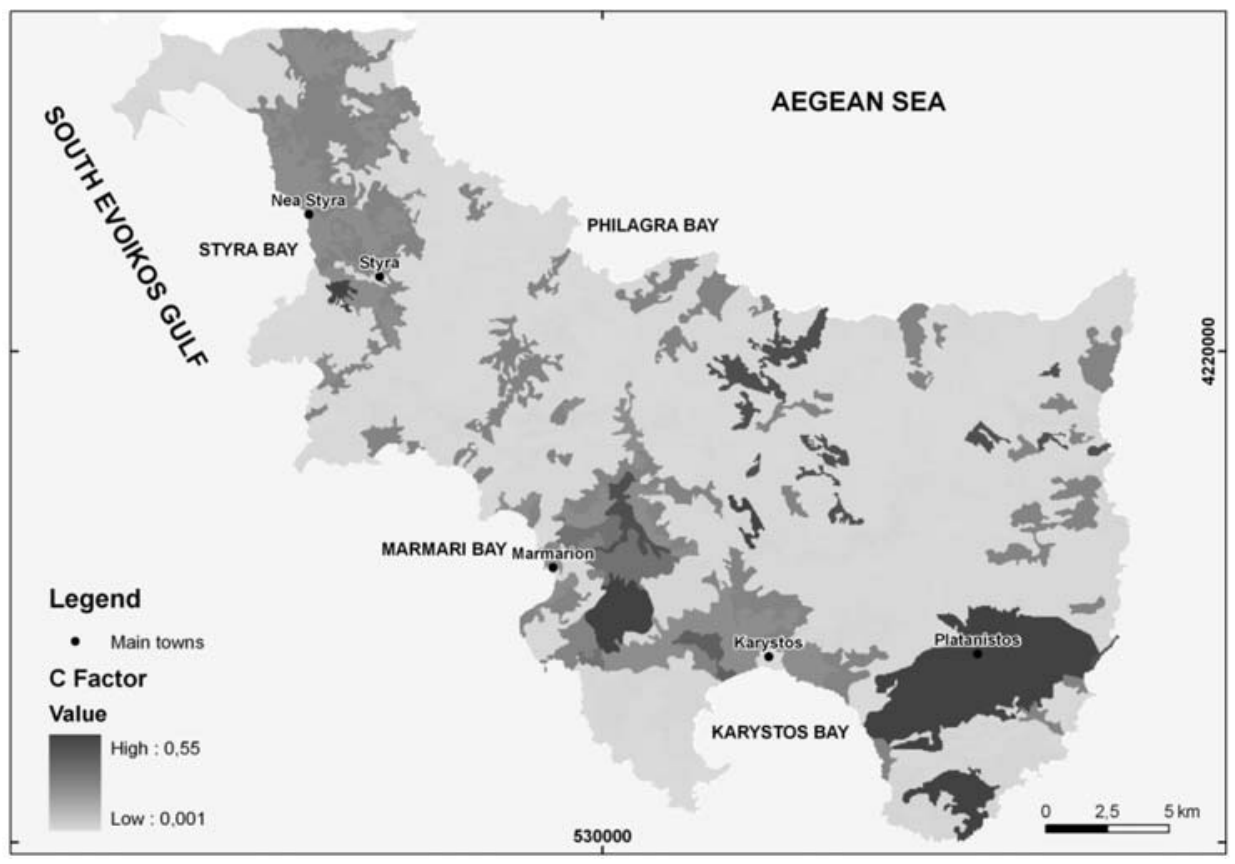

Fig. 5: Spatial distribution map of the cropping management factor in the study area.

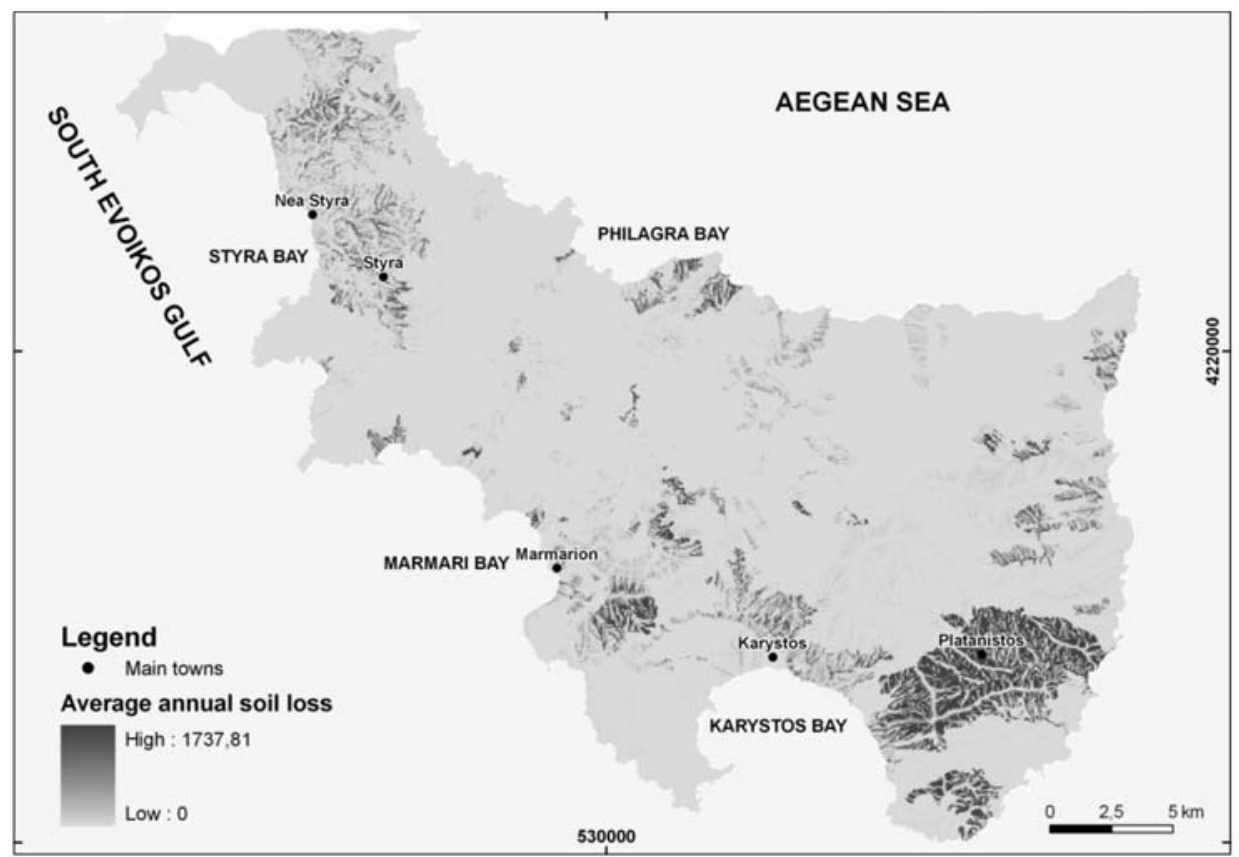

Fig. 6: Spatial distribution map of the average annual soil loss in the study area. 
Finally, the implementation of Universal Loss Equation in GIS by multiplying the above described raster files that corresponds to the five factors of the USLE equation, gave the spatial distribution map of the average annual soil loss potential (A) in tons per acre per year in Southern Evia Island (Fig. 6). This was accomplished in ArcGIS by using the raster calculator tool. The highest computed rate of soil erosion potential is 1,737 tons per acre per year. Generally, the highest rates are in the affected areas by the wildfires of 2007 and 2009 and in the areas where the slope exceeds approximately 30 degrees. The final map should be interpreted as the maximum possible extent of erosion.

\section{Conclusions}

The purpose of this study was the identification of the soil erosion-prone areas in Southern Evia Island using the well-known Universal Soil Loss Equation (USLE) and GIS, as it has become increasingly apparent that computer based GIS can provide the means to model soil erosion effectively. A set of factors as identified in the USLE were studied and reviewed. These include the rainfall erosivity factor (R-factor), the soil erodibility factor (K-factor), the slope and slope length factor (LSfactor), the cropping management factor (C-factor) and the erosion control practice factor (P-factor). These factors which consist of a set of logically related geographic features and attributes were used as data input.

Analysis of monthly rainfall data of the past fourteen years gave the R-factor. The K-factor was calculated based on the geological maps, while it is originally based on soil analysis data, because of the lack of precise and reliable soil datasets for the study area. Digital elevation model (DEM), interpolated from elevation contours, was used to generate the LS-factor. Spatial land cover, extracted from CORINE database on a scale of 1:100.000, was used to determine the spatial C-factor, while photo-interpretation led to the identification of the areas that severely affected by the 2007 and 2009 wildfires in Southern Evia Island. Each of the above mentioned USLE factors, with associated attribute data, was digitally encoded in a GIS database to eventually create the corresponding thematic layers. Then, these layers were spatially overlaid to produce the resultant layer, which yielded the spatial distribution map of the average annual soil loss in the study area.

From the analysis it is evident that severe soil loss covers an area (150 tons/hectares/year) of about $14 \%$. The highest average soil loss was occurred in areas that were affected by the wildfires of 2007 and 2009, while the lowest soil loss rate was found in forest areas. These results proved that soil erosion rates can reach alarming levels in rugged terrain after wildfires and measures to reduce the amount of soil erosion need to be taken at these areas, where plant material and the litter layer that break up the intensity of severe rainstorms is destroyed. The severe soil loss from areas with high erosion rates will cause potential flood risk mainly in lowlands and coastal areas of Karystos Bay. This is caused because eroded soil has decreased capacity to absorb water and the increased runoff can lead to downstream flooding and local damage to property near these areas. In addition, the increased accumulation of eroded materials from watercourses and their deposition in these areas can result in extra damages after flood events. Moreover, vegetation cover strongly influence the erosion process, as due to high vegetation cover such as in forest areas annual soil loss rate seems to be low, in contrast to the burned areas, where little vegetation cover results in high erosion rates.

\section{References}

Brady, NC., Weil RR 1999. The nature and properties of soils. Prentice Hall, Upper Saddle River, New Jersey, $881 \mathrm{pp}$

Cebecauer, T., Suri, M., Hofierka, J., Fulajaitar E 2000. Corine land cover in the contex of soil erosion 
assessment at regional scale.http://www.corine.dfd.dlr.de/media/download/ws-clc_celecauer_et-al.pdf

Dabral, PP., Murry, RL., Lollen, P., 2001. Erodibility status under different land uses in Dikrong river basin of Arunachal Pradesh. Indian. Soil Conserv., 29(3), 280-282.

Descroix, L., Mathys, N. 2003. Processes, spatio-temporal factors and measurements of current erosion in the French Southern Alps: a review. Earth Surface Processes and Landforms, 28, 993 - 1011.

Desmet, PJ, Govers, G 1996. A GIS-procedure for the automated calculation of the USLE LS-factor on topographically complex landscape units. Soil Water Conserv 51(5), 427-433

Dregne, H. E. 2002. Land Degradation in the Drylands. Arid Land Research and Management, 16, 99 132.

ESRI, 2005. ArcDoc for ArcGIS, version 9 Help on CDROM.

Foster, GR., Mc Cool, DK., Renard, KG., Moldenhauer, WC., 1991. Conversion of the Universal Soil Loss Equationti SI metric units. Soil Water Consev., 36, 356-359.

IGME, 1977. Geological Map of Greece (Rafina sheet), scale 1:50.000.

IGME, 1991. Geological Map of Greece (Karistos-Platanistos sheet), scale 1:50.000.

Karydas, C., Sekuloska, T., Silleos, G. 2009. 'Quantification and site-specification of the support practice factor when mapping soil erosion risk associated with olive plantations in the Mediterranean island of Crete. Environmental Monitoring and Assessment 149, 19-28.

Mitchell, J., \& Bubenzer, G. D. (1980) Soil loss estimation. In Kirkby, M. J., \& Morgan, R. P. C. (Eds.) Soil erosion, John Wiley \& Sons: Chichester.

Moore I, Burch G 1986a. Physical basis of the length-slope factor in the universal soil loss equation. Soil Sci Soc Am 50,1294-1298.

Moore I, Burch G 1986b. Modeling erosion and deposition: topographic effects. Trans Am Soc Agr Eng 29(6),1624-1630, 1640

Thampapillai, DA., Anderson, JR., 1994. A review of the socio-economic analysis of soil degradation problem for developed and developing countries. Rev. Mark Agric. Econ., 62, 291-315.

Van Der Knijff, J.M., Jones, R.J.A. and Montanarella, L., 2000. Soil Erosion Risk Assessment in Europe, EUR 19044 EN, 34pp.

Wischmeier WH, Johnson CB, Cross BV (1971) A soil erodibility nomograph for farmland and construction sites. Soil Water Conserv 26 (5),189-193

Wischmeier, W.H. and Smith, D.D. 1978. Predicting Rainfall Erosion Losses. USDA Agriculture Handbook No.537. 